Gut, 1982, 23, 297-303

\title{
Technical hazards of using nutritive mixtures in bags for cyclical intravenous nutrition: comparison with standard intravenous nutrition in 48 gastroenterological patients
}

\author{
B MESSING,* M BELIAH, F GIRARD-PIPAU, D LELEVE, AND J J BERNIER \\ From the Unité de Recherches sur la Physiopathologie de la Digestion, Hôpital Saint-Lazare, Paris, and the \\ Laboratoire de Bactériologie, Hôpital Saint-Lazare, Paris, France
}

\begin{abstract}
SUMMARY Three methods for dispensing nutritional solutions are compared in 48 patients with gastrointestinal diseases on intravenous nutrition during 3582 days. The protocol for intravenous nutrition applied by the nursing team and the solutions used were the same in the three groups. In group A standard bottles were used, while in group B, 31 PVC-disposable bags were used-with fat emulsion included (group B1) or with fat excluded (group B2). When fat was excluded from the bags it was infused separately from a bottle. The mixtures were made under laminar flow by the nursing team who applied a strict protocol which included bacteriological testing. The infection rate observed in the bags was $0.046 \%$. The rate of septic complications was not significantly reduced in group B2 or Bl compared with group A; the type of container used was therefore unimportant and the key was the aseptic handling of the intravenous solutions. The rate of mechanical complications, mainly due to catheter obstruction, was higher $(P<0.001)$ when fat was included in the bags-that is, in group B1-than in groups B2 and A. For 26 patients a cyclical regime of intermittent feeding was easier to manage when bags were used. In group B, this system replaced the continuous method in $75 \%$ of all therapeutic days without adverse effect; it improved compliance and allowed ambulatory treatment. The use of cyclical feeding with separate fat infusions has further reduced the hazards of intravenous nutrition and allowed the development of a programme that can be implemented at home.
\end{abstract}

Whether or not mechanical and infective complications ${ }^{1-3}$ occur in intravenous nutrition depends on three essential features: (1) the method of inserting a venous line by medical or surgical staff with or without the use of a subcutaneous tunnel, (2) the nature of the materials used: catheter(s), nutritive line(s), nutritive containers (bottles or bags), and (3) the expertise and motivation of the nursing team involved in the 'treatment' of the system. ${ }^{4-10}$

Since 1978, we have worked to define an optimal technique of intravenous nutrition which minimises its mechanical and septic complications. ${ }^{11} \mathrm{We}$ report our experience from September 1978 to

*Address for reprint requests: B Messing, INSERM U54, Hôpital Saint-Lazare, 107 bis Rue du Faubourg Saint-Denis, 75475 Paris Cedex 10, France.

Received for publication 30 July 1981
April 1980. This study concerns 48 patients who have been treated in Saint-Lazare Hospital for 3582 days of intravenous nutrition. Three methods of dispensing nutritional solutions are compared: either in standard containers (bottles) used for 1414 days of therapy (group A) or 31 PVC disposable bags used for 2168 days (group B). In this group the nutritive mixtures were made with fat emulsion (B1) and without (B2). Nocturnal cyclical intravenous nutrition was also applied during 2032 days of therapy in 26 patients of the present series.

\section{Methods}

\section{PATIENTS}

Forty-eight patients, 30 men and 18 women, with a mean age of 41 years (range, 17-78 years) were hospitalised in the artificial nutrition unit, and received a total of 3582 days of intravenous 
Table 1 Diagnosis and outcome of patients after intravenous nutrition

\begin{tabular}{|c|c|c|c|c|c|c|c|}
\hline \multirow[t]{3}{*}{ Diagnosis } & \multirow[t]{3}{*}{ No. } & \multirow{3}{*}{$\frac{\text { Sepsis risk }}{\text { Infection foci }}$} & \multirow{3}{*}{$\begin{array}{l}\text { Corticosteroids } \\
\text { (no.) }\end{array}$} & \multicolumn{4}{|c|}{ Outcome } \\
\hline & & & & \multirow{2}{*}{$\begin{array}{l}\text { Surgery } \\
\text { (no.) }\end{array}$} & \multirow{2}{*}{$\begin{array}{l}\text { Death } \\
\text { (no.) }\end{array}$} & \multicolumn{2}{|c|}{ Rehabilitation nutrition } \\
\hline & & & & & & Artificial & Normal \\
\hline & 7 & $\begin{array}{l}\text { Cellulolymphangitis, cutaneous } \\
\text { necrosis, pyelonephritis }\end{array}$ & 1 & 3 & $1^{*}$ & $\begin{array}{l}\text { Enteral } 1 \\
\text { IVN-D } 2\end{array}$ & $3 / 7$ \\
\hline \multirow{7}{*}{$\begin{array}{l}\text { Crohn's disease } \\
\text { Ulcerative colitis } \\
\text { Coeliac disease } \\
\text { Short gut syndrome } \\
\text { Jejunoileitis } \\
\text { Exudative enteropathy } \\
\text { Jejunal fistulae } \\
\text { Sub-occlusion: post surgery } \\
\text { Caustic stenoses } \\
\text { Pancreatitis, oseophageal giant } \\
\text { ulcer, } \alpha \text { chain disease }\end{array}$} & 7 & Cholecystitis & 4 & 1 & $1^{*}$ & & $6 / 7$ \\
\hline & 8 & & 7 & 3 & & & $7 / 8$ \\
\hline & 5 & Tuberculosis & 3 & 2 & & & $4 / 5$ \\
\hline & $\begin{array}{l}5 \\
4\end{array}$ & $\begin{array}{l}\text { Periosteal abscess, pyelonephritis } \\
\text { Necrotising enteritis }\end{array}$ & $\begin{array}{l}1 \\
2\end{array}$ & $\begin{array}{l}3 \\
1\end{array}$ & $\begin{array}{l}2 \uparrow+1 \S \\
1 \ddagger\end{array}$ & $\begin{array}{l}\text { IVN-D } 1 \\
\text { IVN-D } 2\end{array}$ & $\begin{array}{l}1 / 5 \\
1 / 4\end{array}$ \\
\hline & $\begin{array}{l}2 \\
2\end{array}$ & $\begin{array}{l}\text { Pneumonia } \\
\text { Abdominal abscess }\end{array}$ & $\begin{array}{l}0 \\
0\end{array}$ & $\begin{array}{l}2 \\
1\end{array}$ & $\begin{array}{l}0 \\
1++1^{*}\end{array}$ & & $\begin{array}{l}2 / 2 \\
0 / 2\end{array}$ \\
\hline & $\begin{array}{l}3 \\
2\end{array}$ & & $\begin{array}{l}0 \\
0\end{array}$ & $\begin{array}{l}0 \\
2\end{array}$ & $\begin{array}{l}0 \\
0\end{array}$ & & $\begin{array}{l}3 / 3 \\
2 / 2\end{array}$ \\
\hline & 3 & Pneumonia, angiocholitis & 0 & 2 & 0 & & $3 / 3$ \\
\hline
\end{tabular}

Ten of the 48 patients died: two during intravenous nutrition ( $¥)$ and four in the postoperative course $(\dagger)$ due to a complication of primary disease. Three deaths after the hospital stay were due to neoplasia $(*) ;$ the last one was due to suicide $(\S)$. No death could be attributed to intravenous nutrition. Thirty-one of the 48 patients were at increased risk of sepsis during intravenous nutrition either because of corticosteroid treatment $(n=18)$ or a focus of infection $(n=13)$. IVN-D: intravenous nutrition at homc.

nutrition from September 1978 to April 1980. The criteria used in selecting patients for intravenous nutrition were (1) a severe nutritional disease with malnutrition with or without medical or surgical malabsorption unresponsive to full medical treatment, (2) the need for a perioperative nutritional aid, particularly when the upper gastrointestinal tract or small bowel was occluded. The average duration of intravenous nutrition was 75 days (range, 16-343 days). The diagnosis and outcome of these patients are presented in Table 1 . There were 10 deaths: two during the intravenous treatment and four during the post-surgery period, four while completing their intravenous nutrition. No death was due to this method of treatment. In the remaining 38 patients rehabilitation was normal in 32 cases but was followed by continuing nutritional support in six cases: five received intravenous nutrition (four of them while living at home) and one received enteral nutrition. Thirty-one of these 48 patients were considered to be at increased risk of sepsis during this method of feeding either because they were being treated with corticoids ( 18 cases) or because there was a focus of infection (13 cases); 29 of 48 patients developed one or several attacks of fever during their course of intravenous nutrition.

\section{TECHNIQUE}

The silicone catheters were inserted surgically in theatre. The catheters were introduced by the internal or external jugular veins, the endovenous extremity of the catheter being located under radiographic control at the inferior part of the superior vena cava. A prethoracic subcutaneous channel, $15-25 \mathrm{~cm}$ long, was made. The external end of the catheter was fastened to the skin at 1.5 to
$2.5 \mathrm{~cm}$ from its cutaneous aperture, the whole being covered, after aseptic cleansing, with an occlusive dressing (Steripad, Johnson and Johnson). The external luerlock of the catheter was connected during the perfusion to a $2 \mathrm{~m}$ joint (Lectocath, Vygon). Between perfusions the extremity of the catheter was shut off by a female luerlock with a Latex plus heparin cap (Vygon). This allowed the injection of isotonic $\mathrm{NaCl}(2 \mathrm{ml})$ plus heparin $(0.5 \mathrm{ml})$ immedately if the intravenous line blocked. The flow(s) of infusion(s) were controlled by different types of pump, some of which were portable for use with mobile patients. According to the number of patients under care in the ward (on average six, range, three to nine), the nursing team included from one to three members per squad. All the aseptic manipulations involved in making the nutritive mixtures in bags or handling the nutritive line(s) were safeguarded by sterile iodised compresses and were undertaken by a qualified and motivated nursing team, wearing surgical blouse, mask, cap, and sterile gloves.

The introduction on the market of 3 to 3.51 disposable bags for intravenous nutrition made possible the use of nutritive mixtures without dramatically increasing the cost. During this study we therefore replaced the system of bottles (six to nine per day) connected to two or three nutritive lines by the system of bags (one PVC bag Dubernard per day) connected to a single nutritive line. Mixing the solutions under laminar flow was undertaken five times a week by two members of the nursing team. From 15 to 20 nutritive mixtures in bags were made during four to five hours by two trained nurses. The filling of one bag invloved 42 (40-45) manipulations including the introduction of protein, energy, and additive solutions. After the 
bags had been filled, the maximum time of storage at $4^{\circ} \mathrm{C}$ under wrapping was 96 hours for the complete glucose-lipid-protein-mixture and 15 days for the glucose-protein mixture. The nutritive mixtures were made by the introduction of the solutions in the following order: glucose, amino acids, electrolytes, trace elements, with or without the final addition of the fat emulsion. According to variable fluid and protein energy needs for the patients and the availability of pharmaceutical products, the following solutions were used: glucose to 10 to $50 \%$, Intralipid 10 or $20 \%$, Vamin and Vamin fructose $(9.4 \mathrm{~g}$ nitrogen/1, fructose 100 $\mathrm{g} / \mathrm{l})$, or Aminosol (12.8 g nitrogen/l), or Totamine (12.4 g nitrogen/l). These amino acids solutions represented $42.9 \%, 24.24 \%, 28.7 \%, 4.2 \%$ respectively of the used amino acid solutions. Electrolytes, trace elements (Addamel), and vitamins (Polyvitamins) were almost routinely added to the intravenous mixtures. Because pretesting showed that precipitation occurred when phosphorus plus Addamel was introduced into Vamin $\mathrm{N}$, the nutritive mixtures including the amino acid solution were made with one of the two additives on alternate days.

A bacteriological analysis (aerobic and anaerobic in Freiter chamber) was systematically carried out on the first and last prepared bottles when they were filled with the nutritive mixtures. Bacteriological testing of the bags was done during the infusion if a fever occurred and systematically on one out of 10 bags at the end of the infusion. When infection was suspected the following bacteriological tests were made: (1) on the bottle(s) (or the nutritive mixture) during the infusion, (2) several peripheral blood cultures plus one trans-catheter blood culture, and (3) one swab from where the catheter entered the skin. If the catheter had to be removed the internal part was used for bacteriological testing according to a technique previously described, ${ }^{13}$ while the other part of the catheter was opened longitudinally for assessing any obstruction.

\section{STATISTICAL METHODS}

In each group of patients treated by the different methods of dispensing nutritional solutions, the rates of mechanical complications and those due to sepsis were estimated by the method of Kaplan and Meier ${ }^{14}$ and compared by log Rank tests. ${ }^{15}$ When appropriate, Fisher and unpaired $t$ test were also used.

\section{Results}

For 3582 days of intravenous nutrition in 48 patients, 31 of whom were at an increased risk of sepsis (Table 1), 64 siliconed catheters were inserted (Table 2). Sixteen mechanical complications related to catheters, leading to 15 removals (Table 3). All but four of the catheters were of the Vygon silicone type, the majority having the code no 180.20 . There were eight incidents of sepsis related to catheters, and this led to their being removed (Table 4). The average life of the catheters was 56 (one to 343 days). This corresponds to an uncomplicated life (days of intravenous nutrition: number of incidents of complications that led to the removal of catheters) of 156 days. The frequency of septic

Table 2 Intravenous nutrition: surgical venous catheterisation $(n=64)$

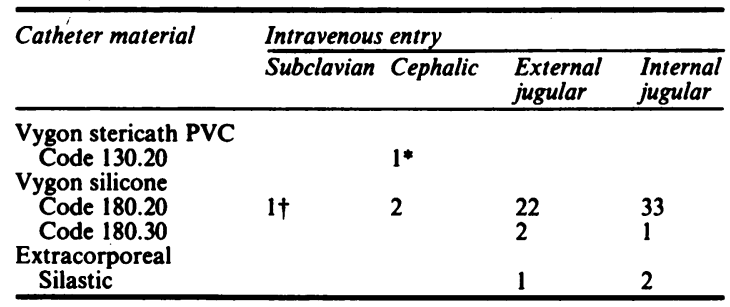

Surgical venous catheterisation (except $\dagger$ ): insertion of soft silicone catheters (except *: insertion before and immediate removal after admission to the ward) and realisation of prethoracic subcutaneous route from 15 to $25 \mathrm{~cm}$ long.

Table 3 Mechanical complications of intravenous nutrition $(n=16)$

\begin{tabular}{llll}
\hline $\begin{array}{l}\text { Type of } \\
\text { complication }\end{array}$ & \begin{tabular}{l} 
Catheter \\
\cline { 2 - 3 }
\end{tabular} & $\begin{array}{l}\text { Delay } \\
\text { Withdrawal Reinsertion }\end{array}$ & Nutrition \\
& & Type Rhythm* \\
\hline
\end{tabular}

\section{External}

jugular vein

phlebitis 1

Kinked

catheter 1

Migration 1

Occlusion 1

Occlusion 1

$\begin{array}{rr}\text { Occlusion } 1 & + \\ 2 & + \\ 3 & + \\ 4 & + \\ 5 & + \\ 6 & + \\ 7 & + \\ 8 & + \\ 9 & + \\ \text { Migration } 1 & + \\ 2 & + \\ \text { Occlusion } 1 & +\end{array}$

*C: continuous. D: discontinuous.

Fifteen of sixteen complications necessitated withdrawal of the catheter. The insertion of a second catheter to prolong intravenous nutrition was done in nine cases. The frequency of catheter occlusion was not significantly different between continuous nutrition (one for 310 days) and cyclic nutrition (one for 339 days). In group A standard containers (bottles) were used during 1414 days (21 patients-27 catheters). In group B, 31 PVC bags were used for dispensing the nutritive mixtures: in group $B_{1}$, complete nutritive mixtures were used for 869 days (22 patients, 27 catheters); in group $B_{2}$, nutritive mixtures were used for 1299 days (five patients, 10 catheters) and fat emulsion was infused separately in a bottle. 
Table 4 Septic complications during intravenous nutrition $(n=8)$

\begin{tabular}{|c|c|c|c|c|c|c|c|c|c|}
\hline $\begin{array}{l}\text { Type of } \\
\text { complication }\end{array}$ & & $\begin{array}{l}\text { Fever } \\
\text { abatement* } \\
\pm\end{array}$ & $\begin{array}{l}\text { Blood } \\
\text { cultures }\end{array}$ & $\begin{array}{l}\text { Blood } \\
\text { culture through } \\
\text { catheter }\end{array}$ & $\begin{array}{l}\text { Catheter } \\
\text { culture }\end{array}$ & Organism & $\begin{array}{l}\text { Delay of } \\
\text { complication } \\
\text { (days) }\end{array}$ & Nutrition & Rhythm + \\
\hline \multirow[t]{2}{*}{ Local } & 1 & + & $0 / 3$ & + & + & $\begin{array}{l}\text { Staphylococcus } \\
\text { epidermidis }\end{array}$ & 30 & A & C \\
\hline & 2 & + & $0 / 3$ & + & - & $\begin{array}{l}\text { Staphylococcus } \\
\text { epidermidis }\end{array}$ & 17 & A & C \\
\hline \multirow[t]{3}{*}{ Bacteriaemia } & 1 & + & $1 / 6$ & - & + & $\begin{array}{l}\text { Staphylococcus } \\
\text { epidermidis }\end{array}$ & 28 & A & C \\
\hline & 2 & + & $1 / 3$ & - & + & $\begin{array}{l}\text { Staphylococcus } \\
\text { epidermidis }\end{array}$ & 1 & A & C \\
\hline & 3 & + & $1 / 3$ & + & + & $\begin{array}{l}\text { Pseudomonas } \\
\text { cepacia }\end{array}$ & 13 & A & C \\
\hline \multirow[t]{2}{*}{ Bacteriaemia } & $1^{*}$ & + & $1 / 2$ & - & + & $\begin{array}{l}\text { Enterobacter } \\
\text { cloacae } \\
\text { Escherischia } \\
\text { coli }\end{array}$ & 26 & $\mathbf{B}_{1}$ & C \\
\hline & 2 & + & $1 / 2$ & - & + & $\begin{array}{l}\text { Staphylococcus } \\
\text { epidermidis }\end{array}$ & 20 & $\mathbf{B}_{1}$ & D \\
\hline Septicaemia & $1^{*}$ & - & $4 / 5$ & + & + & $\begin{array}{l}\text { Staphylococcus } \\
\text { aureus }\end{array}$ & 183 & $\mathbf{B}_{2}$ & D \\
\hline
\end{tabular}

†C: continuous. D: discontinuous.

Two foci of infection were present at the moment of catheter sepsis; Biangiocholitis, S $_{1}^{*}$ Staphylococcus aureus angina. The frequency of catheter-related sepsis during cyclic nutrition was one for 1016 days of nutrition; during continuous nutrition it was one for 258 days of nutrition. X: fever abated in less than 24 hours $( \pm)$. In group A standard containers (bottles) were used during 1414 days (21 patients, 27 catheters). In group B, 31 PVC bags were used for dispensing the nutritive mixtures: in group $B_{1}$ complete nutritive mixtures were used for 869 days (22 patients, 27 catheters); in group $B_{2}$, nutritive mixtures were used for 1299 days (five patients, 10 catheters) and fat emulsion was infused separately in a bottle.

complications was therefore only one for 448 days and of mechanical complications one for 239 days of intravenous nutrition.

The rates of septic and mechanical complications were estimated and compared for the three methods of dispensing nutritional solutions. In group A (21 patients, 27 catheters) bottles were used for 1414 days and five septic and three mechanical (one occlusion) complications were found, septic rate was 0.20 and mechancial 0.13 for 144 days of intravenous nutrition. In group B, 31 PVC bags were used for dispensing the nutritive mixtures for 2168 days; in group B1 (22 patients, 27 catheters) complete nutritive mixtures including Intralipid were used for 869 days. Two septic and nine mechanical (nine occlusions) complications were found. The septic rate was 0.08 and the mechanical 0.35 for 90 days of intravenous nutrient. In group B2 (five patients, 10 catheters) the nutritive mixtures used for 1299 days were made without Intralipid, the fat emulsion being infused separately from a bottle. One septic and three mechanical (one occlusion) complications were found. The septic rate was 0.10 and the mechanical 0.30 for 343 days of intravenous nutrition. Thus rates of sepsis were not significantly different in the three groups A, B1, B2 (Figure), but mechanical rates were higher in group B1 than in groups A and B2 $(P<0.001)$.

The results of the bacteriological testing of the nutritive mixtures showed that at the time of filling, five of $\mathbf{3 7 5}$ prepared bottles (glucose and Intralipid, $0 \%$, electrolytes $1.7 \%$ amino acid solutions $2.7 \%$ ) proved positive (Staphylococcus epidermidis, $\mathrm{n}=3$,
Acinetobacter, $\mathrm{n}=2)$. This means that $[5:(2168$ bags $\times 42$ manipulations)] $0.054 \%$ bacteriological contaminations were found; however, only one bacteriological contamination with Staphylococcus epidermidis was noted in a bag in 157 tests; this corresponds to (1:2168 bags) $0.046 \%$ of infective complications due to the mixing process. In that case, stopping the perfusion sufficed to bring the temperature down. In the $\mathbf{3 5 8 2}$ days of intravenous nutrition, 2032 were performed in 26 patients by nocturnal cyclical intravenous nutrition in order to allow ambulatory treatment during the day. In our study cyclical nutrition was started before the introduction of the nutritive mixtures. When the simpler bag systems were used cyclical intravenous nutrition could be fully developed once disposable bags were routinely available. Cyclical intravenous nutrition represented $22 \%$ of the intravenous nutrition days in group A but $75 \%$ of those in groups B1 and B2. Infusion-free time during cyclical nutrition was from eight to 12 hours per day and the permeability of the catheters between the infusions was maintained by the injection of heparin-saline solution through the Latex luerlock cap. No adverse effects-notably, cardiac or pulmonary failure due to fluid load-were observed during cyclical nutrition conducted with mixed glucose-fat emulsion energy sources. Insulin was not added to this intravenous nutrition, nor did hyperglycaemia, as judged by the absence of glucosuria, occur during infusion; hypoglycaemia was not found after stopping cyclical intravenous nutrition. 


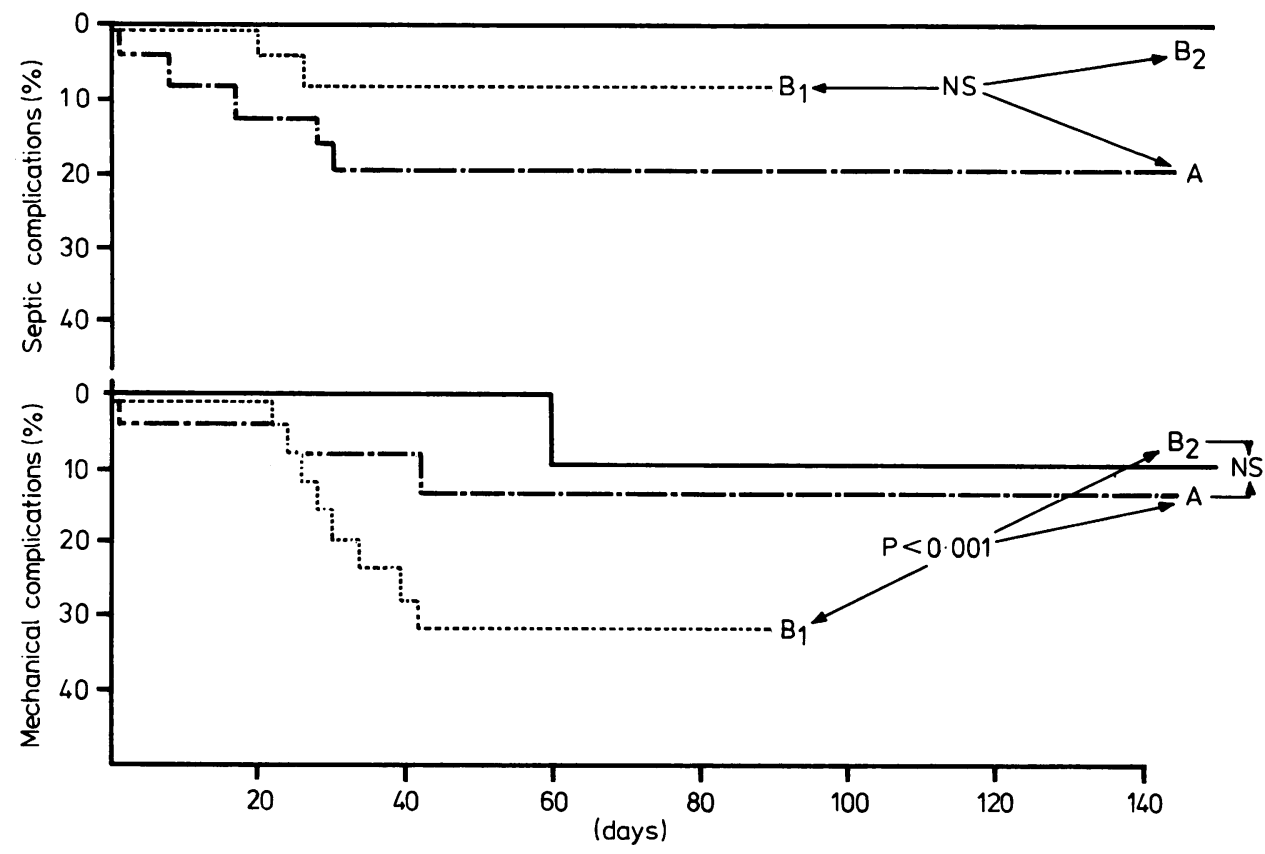

Figure The rates of complications are represented with the method of Kaplan and Meeir. ${ }^{14}$ Each curve in the upper and lower panel is devoted to the different intravenous techniques applied to the three groups of patients: A: intravenous nutrition with separated bottles, $B_{1}=$ intravenous nutrition with complete nutritive mixture in PVC bags, $B_{2}=$ intravenous nutrition with nutritive mixture (without Intralipid), fat emulsion being infused in bottles. Comparisons between the rates of complication were estimated by log Rank tests ${ }^{15}$ (NS: non significant, $P>0.05$ ).

\section{Discussion}

This study showed that the rates of septic and mechanical complications during intravenous nutrition could be modified by methods of dispensing the nutritional solutions. Of the eight instances of septic complications, two could be explained by an endogeneous focus of infection with secondary contamination of the central catheter, but six were directly related to the intravenous techniques. In these cases Staphylococcus epidermidis was responsible on five occasions. This suggests that catheter-related sepsis was commonly due to bacterial contamination at the cutaneous entry side of the catheter and suggests that, with the aseptic handling of the intravenous nutrition devices by the trained nursing team, no significant difference in rates of sepsis appeared between nutrition delivered by bags or by bottles. It has been previously demonstrated, ${ }^{2}{ }^{16}$ however, that to achieve lower catheter sepsis rates requires not only the construction of a subcutaneous tunnel for central catheters 591618 but also a daily and careful cleansing of its entry point, which should then be covered by occlusive dressing. ${ }^{19}$ In our study the sepsis rate complication was 2.6 fold higher in group A than group B patients and 3.9 fold higher during continuous than during cyclical intravenous nutrition. In fact, these slight and insignificant differences seem to be related to the less frequent cleansing and dressing changes during standard ${ }^{19}$ systems (every three days) than during cyclical nutrition when cleansing took place every day, and not to the different containers (bottles or bags) used. All of the septic complications directly related to the catheter occurred during the first month of intravenous nutrition. As the sepsis rate was increased during the initial course of this nutrition, we suggest that this was related to the catheter insertion procedure itself in patients who were depleted by protein calories. Daily catheter dressing changes would therefore be useful in patients who are at high risk for septic complications during the first month of intravenous nutrition. The results emphasise that the maximal reduction in sepsis rate does not require simply that the nutritive mixtures should be in bags but a welldefined protocol which is strictly applied by an efficient nursing team. ${ }^{26-8}$

The mechanical complications could be divided 
into two types, one related to the catheter insertion procedure $(n=5)$ and the second to the intravenous nutrition $(n=11)$. Surgical insertion of silicone catheters in theatre was systematically done because complications due to percutaneous catheter insertion are almost unavoidable ${ }^{1}$ and surgical insertion of a soft silicone catheter is easier than insertion in a medical ward with or without metallic guide. One patient had a kink of the soft catheter after external jugular insertion and this complication was subsequently avoided by constructing a surgical steadying device before the intravenous entry of the catheter.

We have inserted only silicone catheters because of the high frequency of venous thrombosis in PVC catheters. 10112021 After surgical insertion one patient immediately developed an external jugular phlebitis but this was successfully treated with heparin; otherwise venous thrombosis was not clinically evident. In our series the frequency of asymptomatic venous thrombosis could not be evaluated because phlebography was not systematically performed but it was recently demonstrated that this frequency was nil when soft catheters were used.22 Three external migrations of internal jugular catheters were observed after 103 (24-233) days of intravenous nutrition. In these three cases the internal tip of the catheter had been pushed only into the middle part of the inferior vena cava because insertion was difficult because of other PVC catheters having been inserted before the patient's admission to our hospital. For long-term use we favour the intravenous insertion of a silicone catheter into the right atrium with better assessment of the cutaneous fixation of the catheter. Because it was reported that a silicone catheter (Extracorporeal) has an uncomplicated life span of more than $474(60-1200)$ days $^{6}$ we tried three of these catheters in patients on long-term intravenous nutrition on B2 therapy and found its mean life-span to be 202 (90-290) days: two had not been removed one year after the end of the study. However, it seems that silicone Vygon catheters are also very suitable for such long-term nutrition ${ }^{922}$ because four of these had a mean duration of 222 (170-353) days, one being still in situ one year after the end of the study.

The most frequent complication observed in this study has been the progressive obstruction of the catheter's bore by organic and mineral deposit $(n=11)$. This complication has been rarely described when silicone (Rhone-Poulenc) ${ }^{23}$ or PVC bags (Fenwall-Baxter) ${ }^{6}$ are used as containers for nutritive mixtures made with $^{23}$ of without $^{6}$ Intralipid fat emulsion. In one report ${ }^{6}$ the obstruction was complete after four, 10, and 18 months of intravenous nutrition in three of 22 Silastic catheters. In our study, nine of the 11 catheter obstructions were observed in $\mathrm{B} 1$ patients after 37 (22-90) days of nutrition. In this group complete nutritive mixtures included fat emulsion. The rate of mechanical complications was significantly higher $(\mathrm{P}<0.001)$ in $\mathrm{B} 1$ patients than in $A$ and B2 patients, similar rates being observed in these last two groups. The B1 obstruction rate did not seem to be influenced by the cyclical or continuous intravenous procedure because this complication was equally observed and after the same time lag during cyclical nocturnal intravenous nutrition $(n=4,49$ (24-90 days) or during continuous standard intravenous nutrition $(n=5$, 45 (22-40) days). So infusing the fat emulsion separately prevented catheter occlusion when PVC bags were used for periods longer than one month. We also replaced the PVC bags by ethyl vinyl acetate (EVA) bags but continued to exclude nutritive mixtures with fat emulsion in prolonged intravenous nutrition because we also observed catheter occlusions when EVA bags were used.

Cyclical nocturnal intravenous nutrition from 12 to 16 hours was carried out in 26 patients for 2032 days. This method was clearly facilitated by the use of nutritive mixtures connected to one nutritive line. Heparin saline injected through the Latex cap of the catheter at the end of cyclic intravenous nutrition $^{6}$ maintained the catheter's patency between infusion periods lasting up to 72 hours. This heparin lock has allowed the patients to acquire the necessary mobility. ${ }^{24}$ No adverse sideeffect has been observed during or just after stopping cyclic nutrition. ${ }^{24}$ During the infusion-free time the patients could then undergo investigations without risk to their intravenous line; they also had the possibility of physical training and they could walk freely inside or outside the hospital. Cyclical nutrition in hospital has definitely increased the patients' compliance with intravenous nutrition, especially during long-term treatment. Cyclical or standard intravenous nutrition with nutritive mixtures was easier to manage and has required less nursing time than that with bottles. However, because the nursing team made the nutritive mixtures under laminar flow, the same number of nurses was involved in the patient's care. It was calculated that the making of one nutritive mixture in bag required $42(40-45)$ manipulations and that four to five hours were needed to fill 15 to 20 bags. The bacteriological testing during the mixing of solutions was systematically maintained, as any failure in the system could lead to dramatic septic complications; the time lag before the use of the mixture allowed the growth of bacteria. In this 
study only one bacteriological contamination with Staphylococcus epidermidis was noted in the bags and stopping the perfusion in that case sufficed to bring the patient's temperature down. In our data an extremely low percentage $(0.054 \%)$ of positive bacterial testing was achieved during the production of the nutritive mixtures under laminar flow. This emphasises the importance of a motivated and qualified nursing team in intravenous nutrition. Finally, the use of nutritive mixtures without fat, and cyclical nutrition has led to the development of a programme of intravenous nutrition with a low rate of complications. This has allowed us to treat five patients of the present series at home.

We acknowledge with thanks the help of the nursing team of the department of artificial nutrition: $\mathrm{M}$ Beliah, $\mathrm{S}$ Benromdane, $\mathrm{C}$ Caboche, $\mathrm{A}$ Drouin, MJ Itie, G Louis Dit Sully, S Robert, L Roussel.

\section{References}

1 Dudrik SJ, Long JM. Applications and hazards of intravenous hyeralimentation. In current concepts in parenteral nutrition. In: Greep JM, Soeters PB, Wesdorp RIC, Phaf Cur, Fisher JE, eds. Current concepts in parenteral nutrition. The Hague: 1977; 5-20.

2 Fisher JE. Complications of parenteral nutrition. In: Greep JM, Soeters PB, Wesdorp RIC, Phaf CUR, Fisher $\mathrm{JE}$, eds. Current concepts in parenteral nutrition. The Hague: 1977; 171-7.

3 Ricour C, Nihoul-Fekete C, Bertin P, Royer P, Pellerin D: Alimentation parentérale continue par catheter intra cave chez l'enfant. Ann Chir Inf 1972; 13:1-20.

4 Barret A, Couzi M, Vaysse C, Masson J, Gedeon A. La voie veineuse jugulaire externe; catheter en silastic avec trajet sous cutané pour alimentation parentérale chez l'adulte. Rev Med Toulouse 1975; 11:221-7.

5 Filler RM, Eraklis AJ, Rubin VG, Das JB. Long term parenteral nutrition in infants. $N$ Engl J Med 1969; 281:89-94.

6 Jeejeebhoy KN, Langer B, Tsallas G, Chur C, Kuksis A, Anderson $\mathrm{H}$. Total parenteral nutrition at home: studies on patients surviving 4 months to 5 years. Gastroenterology 1976; 71:943-53.

7 Holm I, Wretling A. Prophylaxis against infection and septicemia in parenteral nutrition via central intravenous catheter. Acta Chir Scand 1975; 141:173-81.

8 Messing B. Principes at techniques de la nutrition artificielle. In: Encycl Med Chir Thérapeutique 25967 B10, Paris: $1980 ; 1-12$.

9 Powell-Tuck J, Neilson T, Farell JA, Lennard-Jones. Team approach to long term intravenous feeding in patients with gastrointestinal disorders. Lancet 1978; 2:825-8.

10 Ryan J, Abel R, Abott Wet al. Catheter complications in total parenteral nutrition. A prospective study of 200 consecutive patients. $N$ Engl J Med 1974; 290:751-61.

11 Beraud JJ, Demarquez JL, Diconstanzo J et al. La voie veineuse pour la nutrition parentérale totale de l'adulte. Nouv Presse Med 1979; 8:2347-8.

12 Moghissi K. A technique of superior vena caval catheterisation for prolonged intravenous feeding. J Roy Coll Surg Edinb 1979; 24:178-9.

13 Maki DG, Weise CE, Sarafin HW. A semiquantitative culture method for identifying intravenous catheter related infection. $N$ Engl J Med 1977; 296:1305-9.

14 Kaplan EL, Meier P. Non parametric estimation from incomplete observations. $J$ Am Stat Assoc 1958; 53:457-81.

15 Peto R, Pike MC, Armitage P. Design and analysis of randomized clinical trial requiring prolonged observation of each patient: introduction and design. $\mathrm{Br} J$ Cancer 1976: 34:585-612.

16 Powell-Tuck J, Lennard-Jones JE, Lowes JA, DansoTwum $K$, Shaw EJ: Intravenous feeding in a gastroenterological unit. A prospective study of infective complications. J Clin Pathol 1979; 32:549-55.

17 L'Hirondel C: L'alimentation parentérale complète et prolongée de l'adulte. Paris: Thèse Paris VII, 1973: 11-12.

18 Joyeux M, Astruc B. Traité de nutrition artificielle de l'adulte. (tome II). (In press.)

19 Jarrard MM, Olson CM, Freeman JB. Daily dressing change effects on skin flora beneath subclavian catheter dressings during total parenteral nutrition. JPEN 1980; 4:391-2.

20 Messing B, Poitras P, Bitoun A, Bernier JJ. Thrombophlebitis in intravenous nutrition. Lancet 1976; 2:1351-2.

21 Monsallier JF, Bleichner G. Les thromboses veineuses iatrogènes. Rev Prat 1977; 27:1371-9.

22 Laidlow JM, Powell-Tuck J, Wood SR, Lennard-Jones JE, Bartram CI. the use of a skin tunnelled silicone rubber catheter for parenteral feeding to avoid central venous thrombosis (Abstract). JPEN 1980; 4:604.

23 Solassol C, Joyeux H, Serrou B, Pujol H, Romieu C. Nouvelles techniques de nutrition patentérale à long terme pour suppléance intestinale. $J$ Chir 1973; 105:15-24.

24 Messing B, Pontal PG, Bernier JJ: Metabolic study during cyclic TPN: comparison with standard TPN (Abstract). JPEN 1980; 4:435. 